\title{
Representações da arte funerária: \\ homenagens às pessoas que contribuíram para a educação no Brasil
}

\author{
Funeral art representations: tribute to people \\ concerning education in Brazil
}

\section{RESUMO}

Este artigo propõe uma leitura visual de monumentos funerários que homenageiam a sala de aula, os professores (as) e as personalidades beneméritas que colaboraram para o ensino brasileiro. Seguiu-se o historicismo cronológico das passagens que levaram o homem a se tornar este ser especial - educador do grupo social a que pertence. No aparecimento da palavra escrita, do ofício de escrivão e de livreiro, a professora, a sala de aula e membros da sociedade se completam para construir esse arcabouço merecedor da formação intelectual do homem proveniente da instrução e do conhecimento. As esculturas são representadas no formato de retratos memoriais, bustos, hermas, corpos inteiros e utilizando-se de narrativas que valorizam o universo biográfico dos personagens homenageados. Para reconstruir o contexto de memória das pessoas, tive como suporte conceitos da História da Educação, da História da Arte Funerária, da História da Imagem. A pesquisa de campo realizada nos vários cemitérios secularizados do Brasil foi fundamental para a concretização deste trabalho. Essa memória individual tornou-se pública e acessível a todos que visitam o cemitério.

Palavras-chave: Cemitério secularizado - Arte Funerária - Homenagens póstumas - Educadores no Brasil- Século XX

\begin{abstract}
This article aims to make a visual reading of funerary monuments that honor the classroom, the teachers and the benefactors who collaborated for the Brazilian teaching. A chronological historicism of the passages that led man to become this special being - educator of the social group to which he belongs - was followed. The appearance of the word, the writing, the office of the clerk and the bookseller, the teacher, the classroom, and members of society complement each other to build this framework that deserves the intellectual formation of man originated from instruction and knowledge. The sculptures are represented in the format of memorial portraits, busts, herms, whole bodies and using narratives that value the biographical universe of the honored characters. To reconstruct the memory context of people, I had as support concepts from the History of Education and the History of Art. Field research carried out in the various secularized cemeteries in Brazil was fundamental to the realization of this work. This individual memory has become public and accessible to all who visit the cemetery.
\end{abstract}

Keywords: Secularized cemetery- Funerary Art- Posthumous tributesEducators in Brazil-20th century

* Doutora em Artes pela Universidade de São Paulo (USP). Professora da Pós-Graduação de História da Universidade Federal de Goiás. Membro da Red Iberoamericana de Cementerios Patrimoniales, da Associação Brasileira de Estudos Cemiteriais (ABEC) e do Grupo de Pesquisa Imagens da Morte (UNIRIO-/CNPQ). CV: http://lattes.cnpq.br/0672444382021221 


\section{A escrita como forma de conhecimento e comunicação}

Há todo um reino das imagens, relativas às representações afetivas. Essas imagens unem as pessoas mais do que os saberes relacionados à razão ou à ciência (Durand apud Penin, 1995, p. 8).

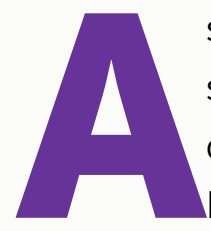

s palavras de Durand reforçam o interesse de demonstrar que os cemitérios secularizados contêm monumentos funerários com uma arquitetura que se utiliza da escultura, da pintura, da escrita e dos adornos para enaltecer a vida dos falecidos. Este artigo propõe uma leitura visual de monumentos funerários que homenageiam alunos, professores e personalidades beneméritas do ensino no Brasil. A demonstração do afeto, do carinho e do amor torna-se pública e fica gravada para que não haja o esquecimento daqueles que fizeram um bem coletivo para a sociedade.

A pesquisa partiu do levantamento do meu acervo pessoal proveniente do trabalho de campo existente desde 1980, no qual acessei sete mil fotografias que registram cemitérios do Brasil, dos demais países da América do Sul e da Europa. Nessa gama de imagens foram consideradas doze obras das primeiras décadas do século $X X$, condizentes com o objetivo deste artigo. Em seguida, consultei os dados de algumas dessas obras, já analisadas por mim e disponíveis no endereço eletrônico <http:artefuneráriabrasil.com.br> lacesso em 30 de setembro). Esse site foi disponibilizado para o público no ano 2000 e traz, em seu acervo, uma catalogação de trinta cemitérios brasileiros. Ele se tornou uma das fontes necessárias para o reconhecimento do cemitério como local de memória, perfilhando o significado histórico de uma sociedade através de seus valores culturais e artísticos revelados por símbolos religiosos e profanos. Essas fontes primárias ajudaram a compreender a importância do ensino e de seus protagonistas.

Para reconstruir o contexto de memória das pessoas homenageadas, tive como suporte livros e artigos voltados à educação que auxiliaram na compreensão e na complexidade da área de ensino e educação na cultura ocidental. Henri-Irénée Marrou, no livro História da Educação na Antiguidade (2017), destaca a Antiguidade mediterrânea como construtora de uma educação clássica, com um sistema de educação coerente e determinado. Ademais, explicita a passagem progressiva de uma cultura de nobres guerreiros para uma cultura de Escriba, seja na região da Mesopotâmia e do Egito, seja da sociedade oriental. Apresenta também o sistema de educação na Antiguidade. Toda essa leitura me ajudou a compreender o quanto as representações da arte clássica fazem parte do escopo de algumas esculturas funerárias aqui consideradas.

O artigo "A professora e a construção do conhecimento sobre o ensino", de Sonia Teresinha de Souza Penin (1995), me fez observar o quanto a professora ganha relevância na cultura escolar, especialmente nas relações que estabelece com os alunos. Só isso seria suficiente para prestar uma homenagem póstuma às professoras, conforme está explícito em algumas obras aqui selecionadas. Já Maria Eliana Novaes, no livro Professora primária. Mestra ou tia (1984) nos fez perceber o momento em que começou a ocorrer a expropriação do saber da professora, que, nas primeiras décadas do século $X X$, ainda não tinha passado por esse 
processo duro e amargo.

Atualmente existe uma literatura ampla sobre a história da arte funerária no Brasil. Pesquisei livros que referendaram uma das obras abordadas (Figura 2), como Cemitérios do Rio Grande do Sul: arte, sociedade, ideologia, organizado por Harry Bellomo (2000), e Mulher: a moral e o imaginário 1889-1930, de Clarisse Ismério (2018). Para desenvolver os conceitos formais das imagens, revisei aminha produção acadêmica, a saber: Arte funerária no Brasil (1890-1930). Ofício dos marmoristas italianos em Ribeirão Preto (2017); Retratos memoriais: uma das formas de perpetuar a memória de "Homens llustres" nos cemitérios secularizados no Brasil (2012); Busto memorial: retrato idealizado convertido em "brasão burguês" póstumo (2015). Sabe-se que os vários tipos de retratos são recursos utilizados com frequência para representar homenagem àqueles detentores do saber.

Quanto à teoria das imagens, comungo com o pensamento de Alberto Manguel (2001, p. 27), quando diz que "atribuímos a elas o caráter temporal da narrativa [...] conferimos à imagem imutável uma vida infinita e inesgotável". Diante dessa afirmação, pretendo "explicar comentários" a respeito das obras selecionadas, e não as explicar. Cada uma carrega o seu mundo, um código que nos habilita a lê-la, e assim vai constituindo suas narrativas, descobrindo o significado moral e ético que a sociedade atribuiu aos figurantes da educação no Brasil. Não tive preocupação em observar a obra como um todo, apenas me detive nas partes dos túmulos que contribuíram para destacar o valor da imagem que tornou-se singular para especificar o valor da escrita, do ensino e dos homenageados(as). Essas fontes secundárias foram completadas com outros livros citados nas referências do artigo.

Metodologicamente, obedeci a uma ordem de passagens que levou o homem a se tornar esse ser especial - educador do grupo social a que pertence. Iniciei por apreender o significado da palavra, da escrita; o ofício do escrivão e do livreiro; a função da professora; a sala de aula e o membro da sociedade civil que ajudou a construir a escola, enfim, essa estrutura merecedora de formação intelectual proveniente do ensino e do conhecimento. Os protagonistas dessa história merecem ser notados de modo especial na "cidade dos mortos" e observei que foram feitas algumas representações de grande valor artístico.

Atualmente, o ensino brasileiro está com novos modos operantes para tratar de assuntos como educação e ensino público, comprometendo a aprendizagem e a formação cultural do aluno, o desempenho dos professores(as) das áreas de humanas, ciências exatas e da saúde, e, consequentemente, ocasionando uma desvalorização desses profissionais vinculados ao ensino e à pesquisa. Foi sempre dessa maneira? Mediante essa realidade perversa, as representações funerárias do período em estudo demonstram que não. Há monumentos instalados nos cemitérios secularizados do Brasil de grande, médio e pequeno porte que auxiliam a compreensão e a valorização da escrita e do livro intimamente imbricados com a formação da aprendizagem e, consequentemente, com a função do professor, daí a necessidade de se realizar o levantamento das obras desse gênero no artigo.

É importante esclarecer sobre a função da palavra desde os tempos primordiais da história e o uso dos sinais para explicar as ideias humanas e torná-las conhecidas através do que é chamado de grafia; os suportes da escrita e os instrumentos utilizados para escrever 
que foram se modificando e se aperfeiçoando no decorrer dos séculos. A escrita registra a linguagem falada por meio de sinais visuais regularmente dispostos de acordo com o tipo de idioma, assunto que não cabe aprofundar no presente artigo. Aqui, interessa mostrar que ela é fundamental para a história, pois permite o armazenamento e a propagação de informações entre pessoas e civilizações, bem como a possibilidade de deixar textos escritos que são passados de geração a geração (Marrou, 2017).

Ao visitar um cemitério secularizado não vejo só monumentos funerários repletos de escultura e adornos, vejo, com muita frequência, nos túmulos, a inscrição da palavra "Saudade", que significa um amálgama de sentimentos que os parentes querem transmitir sobre o falecido nesse local: lembrança nostálgica, pesar pela ausência e dor da separação. Origina-se do latim "solitatem", traduzido como solidão. Um exemplo escolhido para demonstrar o significado dessa palavra está no monumento funerário de Luiza Maria Vieira (1832-1914), que pode ser encontrado no Cemitério Senhor Bom Jesus, fundado em 1890, na cidade de Batatais (SP). ${ }^{1}$ Encontrei com a representação de uma senhora de beleza clássica e de vestes romanas, que segura na mão direita uma pena onde está escrito a palavra "Saudades" em bronze, incrustada na cruz romana de pedra na cabeceira do monumento (Figura 1).

O monumento funerário foi construído, certamente, dentro de uma nova realidade econômica nacional, a partir de 1914, quando os marmoristas começaram a fazer modelos mais sóbrios, empregando materiais mais acessíveis e nacionais, como o granito e a pedra. Agregavam a escultura em mármore de Carrara, influenciada pelos padrões greco-romanos, para distinguir o status social da referida família. A monumentalidade da senhora destoa no monumento e seu gesto tornou-se singular (Borges, 2017). A palavra "Saudade", por sua vez, continua sendo gravada nos inúmeros monumentos funerários, todavia, sem esse ritual de estima especial aos sentimentos que comportam a relação da senhora com o significado da palavra endereçada simbolicamente à falecida.

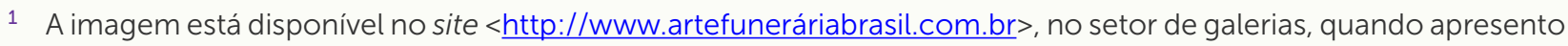
o histórico do cemitério de Batatais. 
Figura 1. Monumento funerário de Luiza Maria Vieira. Pedra, escultura de mármore de Carrara, placas de bronze e tumulo em pedra, 1914

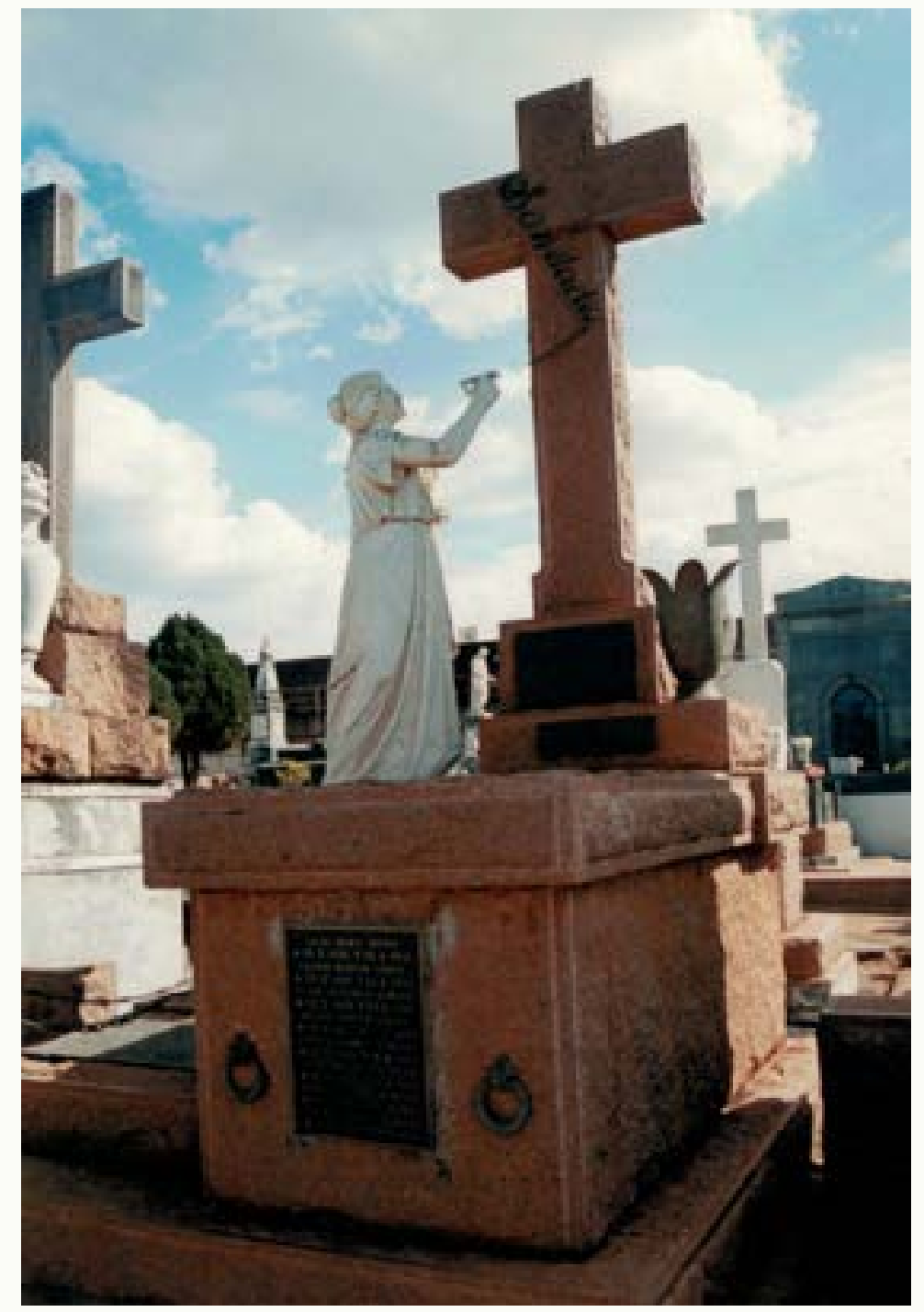

Fonte: Cemitério Senhor Bom Jesus, Batatais. Fotografia: César Mulati.

Repassando a iconografia da escrita, vê-se bem concebida ao visitar o Museu do Louvre, em Paris e encontrar a estátua de calcário pintada intitulada Escriba Sentado (IV ou V Dinastia Egípcia, cidade de Sacara), considerada uma das obras-primas da arte egípcia em função do retrato realista do escriba. O homem, com uma postura elegante, encontra-se sentado em posição ereta, segurando entre as pernas cruzadas o seu instrumento de trabalho: pergaminho de papiro desenrolado pela mão esquerda e, com a direita, segura uma pena; os olhos escuros estão atentos, com olhar frontal voltado ao observador. Intui-se a importância que a sociedade egípcia dava para essa pessoa, que tinha a incumbência de preservar e fazer os documentos. Poucos chegavam a esse estágio em razão da elitização do ofício, transmitido de pai para filho. Diante dessa realidade, a pressão social fez nascer a escola, que ainda não era para todos, mas atingia um pouco mais de jovens, segundo Henri-Irénée Marrou (2017).

O Escriba era considerado, nas sociedades antigas, como o escrivão, ou seja, era aquela 
pessoa que tinha como função escrever e copiar tudo o que fosse necessário - como dados contábeis, registros de compra e venda, serviços administrativos - incluindo anotar a história popular e até escrever textos de ficção, afinal, ele era um servidor administrativo da realeza. Era visto como uma pessoa de classe superior, podendo, inclusive, participar diretamente do exercício do poder. Na Antiguidade, acreditava-se que "a escritura é uma coisa sagrada, de origem e inspiração divina, disposta sob o patrocínio de um Deus" (Marrou, 2017, p. 26). Os Escribas Sumerianos estruturaram a escrita cuneiforme; os Egípcios, o hieróglifo; os Fenícios, o grego. Dessa evolução surgiu o nosso alfabeto, proveniente do greco-romano.

Os locais dos mortos no Egito também contribuíram para a evolução da escrita ao colocarem escritos e desenhos em rolos de papiro, nos túmulos junto das múmias. Os textos tinham como função ajudar o morto em sua viagem para a vida do além e foram escritos, no mesmo espaço, por várias pessoas e em períodos diferentes da história do Antigo Egito. Atualmente, há uma coletânea de imagens no Livro dos Mortos e cito o de Carol Andrews, The Ancient Egyptian book of the dead, de 1996.

O surgimento da escrita é um marco importante na história, transpõe barreiras do tempo e espaço, imortaliza experiências e conhecimentos, além de deixar registros que são reproduzidos e passados para as gerações seguintes. Escolhi o Mausoléu de José Gomes Pinheiro Machado, no Cemitério da Santa Casa de Misericórdia, de Porto Alegre (1843) para caracterizar a importância da escrita através da escultura da Clio, musa da História (Figura 2). Há uma narrativa no conjunto escultórico frontal de ornamentação suntuosa, que reflete a ideologia positivista criada por Augusto Comte (1798-1857) durante a Revolução Industrial, na França, visando a lei dos três estados, a classificação das ciências e a reforma intelectual da sociedade. No Brasil, os militares, e, consequentemente, a Escola Militar, aderiram aos ideais positivistas. Pinheiro Machado ingressou, quando criança, na Escola Militar e, mais tarde, como senador, fundou com outros políticos o Partido Republicano Conservador - PRC (1910), que defendia o programa histórico dos republicanos e as ideias liberais (Silveira, 2000, p. 170). 0 monumento foi custeado pelos cofres públicos por meio de um concurso nacional realizado no Rio de Janeiro. Daí a sua instalação ocorrer somente em 1923, através de um evento apoteótico.

Para o pesquisador José Francisco Alves (2004, p. 202), o senador Pinheiro Machado (1851-1915) foi "o político mais influente (e odiado) na República nos primeiros anos do século XX, até o seu assassinato, na capital federal, em 1915 [...] o túmulo mais dispendioso em cemitérios de Porto Alegre pelo maciço estatuário de bronze e mármore de Carrara nele contido". Há, ainda, o emprego do granito rosa polido, a pátina esverdeada das esculturas em baixo-relevo. O projeto foi realizado pelo escultor português radicado no Rio de Janeiro, Rodolfo Pinto e Couto (1888-1945).

O político é retratado de forma realista, com o peito nu, como um herói romano, e está exposto em um leito de morte encoberto parcialmente pela bandeira nacional, personificando o mártir que morreu defendendo a pátria. À direita do monumento encontra-se afigura de Clio, sentada de frente para o espectador e com o rosto de lado, olhando para o estadista. Os traços do rosto são de uma beleza clássica. Ela segura um livro para registrar a vida do político para 
as futuras gerações, ali representadas pelos adolescentes e crianças aos pés do Jacente. Sabese que a musa e suas oito irmãs, sob a assistência de Apolo, inspiravam as artes e as ciências, restabelecendo a paz entre os homens.

Clio, nesse caso, tem a função de escrever a memória, divulgar e perpetuar as realizações do grande herói da República do Rio Grande do Sul, postura de uma mulher educadora"Mestra da vida" -, conforme referenda Clarisse Ismério (2018, p. 64). A mulher madura, altiva e elegante na cabeceira do jazigo representa a República - "Mãe Pátria" -, que lamenta a perda do filho. Na tipologia cívico-celebrativa desenvolvida por Bellomo (2000, p. 172) o monumento comemora a memória desse ilustre político rio-grandense.

Figura 2. Mausoléu de José Gomes Pinheiro Machado, 1923. Esculturas em bronze e em mármore de Carrara. Monumento revestido de granito róseo polido

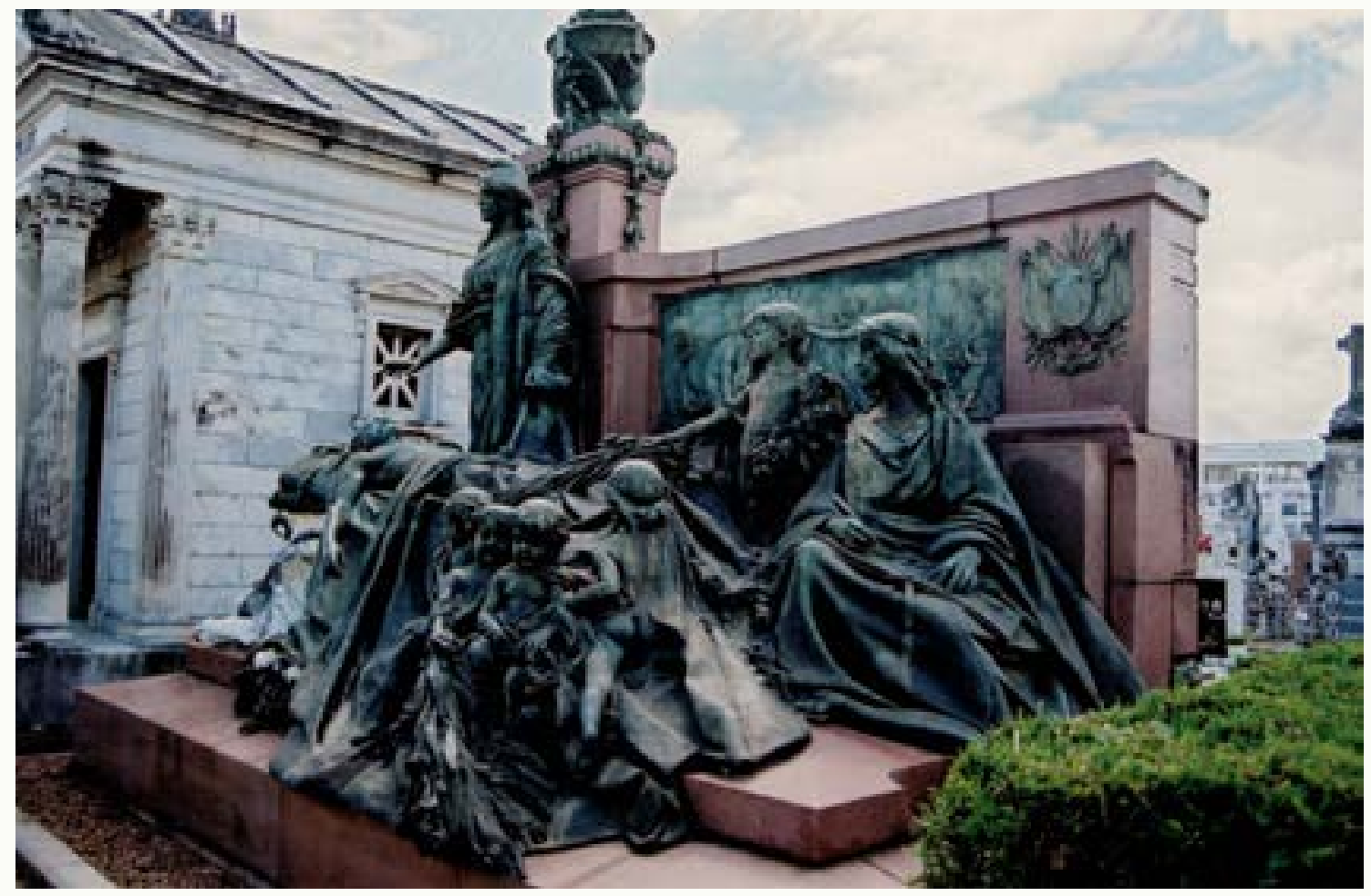

Fonte: Cemitério da Santa Casa de Misericórdia de Porto Alegre (RS), escultor Rodolfo Pinto e Couto, Rio de Janeiro. Fotografia: Beatriz Raucher.

O livro que Clio carrega é um objeto transportável, composto por páginas, cabendo a ela transcrever a vida do político José Gomes Pinheiro Machado. Sabe-se que anteriormente ao período greco-romano os suportes para a escrita foram variados, como tabuletas de argila ou de pedra e cilindros de papiro, e só no período romano criou-se o formato de códice de pergaminho, de fácil costura e manuseio - o livro. Na Idade Média, o pergaminho foi substituído pelo papel e, com a invenção da impressão, no século XIV, iniciou-se a feitura do livro em maior escala. Na abadia de Fontevraud, na França, encontra-se o sepulcro da Rainha Eleonora da Aquitânia (1122-1204), que aparece em posição jacente "lendo por toda eternidade", segundo 
Alberto Manguel (1997, p. 176). Sabe-se que ela se tornou Patrona de figuras literárias da sua época.

A arte cristã desenvolveu inúmeras representações tanto em pintura como em escultura, em que aparecem as mães ensinando os filhos a ler os livros. Como exemplo citamos as obras que constam no livro Uma história da leitura (Manguel, 1997, p. 91 e 243): Santa Ana com a jovem Maria (Musée Lorrain, Nancy), Maria e o Menino Jesus (Igreja de Luat, Fresnayle Luat, Oise), obras do século XV. Para Alberto Manguel, a noção de "Cristo lendo o Velho Testamento era considerada essencial para tornar explícita a continuidade das Escrituras". Chamo também a atenção para a obra A Anunciação, de Simone Martini (Galeria Degli Uffizi, Florença, 1333), na qual o pintor representa a Virgem Maria recebendo o anjo Gabriel, que anuncia a concepção do filho de Deus, Jesus. Ela segura um livro com a mão esquerda ao receber a notícia.

Já no século XIX o livro se populariza e, consequentemente, a informação (Febvre e Martin, 1992). O cemitério tornou-se, então, um local propício para representar os livros devido a um de seus significados, o registro da memória do morto. Nos cemitérios secularizados é comum encontrar livros esculpidos em mármore, que contêm escrituras que sintetizam a vida moral do falecido e aí se inscrevem mensagens de amor e dados de identificação do morto - o epitáfio -, tornando-se o último discurso proferido ao morto. Os epitáfios apareceram imitando inscrições da Antiguidade Clássica, objetivando afirmar a identidade do morto. No século XIX, eles já estão ligados ao sentimento de piedade para com o falecido. Traduzem um sentimento profundo de dor, subscrevendo poemas em versos, elogios intermináveis com poucos detalhes pessoais. No século $X X$, as frases mudam aos poucos e ficam mais sucintas, com textos já prontos, apenas dados pessoais que seguem modelos expostos nos catálogos das marmorarias, com expressões estereotipadas e convencionais, com a persistência da palavra "Saudade", conforme documentei anteriormente (Borges, 2017).

Não se sabe como era o túmulo que contém o livro aberto de Francisca (†4/10/1916), pertencente à família Paula Assis, pois a peça está exposta isoladamente na entrada do Cemitério da Saudade de Ribeirão Preto (1892) como motivo de decoração em um pedestal (Figura 3). O epitáfio consta apenas a data da falecida e o nome da família. O que me chamou a atenção foi a colocação da Alegoria da Saudade em alto-relevo, debruçada no meio do livro aberto. Sabe-se que os anjos são imagens provenientes da fé cristã que personificam o ser espiritual, que exerce o ofício de mensageiro entre Deus e os homens, merecendo, então, uma atenção especial na estrutura figurativa do cemitério. Nessa alegoria o anjo criança apresenta-se em estado de meditação, com expressão triste e serena ao colocar uma coroa de flores acima do nome da falecida, uma de suas versões constituídas. São as "flores da recordação" (Borges, 2017, p. 261). Ele está meio de lado, seminu, um corpo inspirado nos modelos da escultura juvenil barroca, cabelos encaracolados em torno do rosto redondo, com um pequeno pano esvoaçante tampando apenas os órgãos genitais e com asas dispostas abertas para o alto, indicando o voo aos céus. 
Figura 3. Livro aberto da Francisca, mármore de Carrara, 1916.

Família Paula Assis

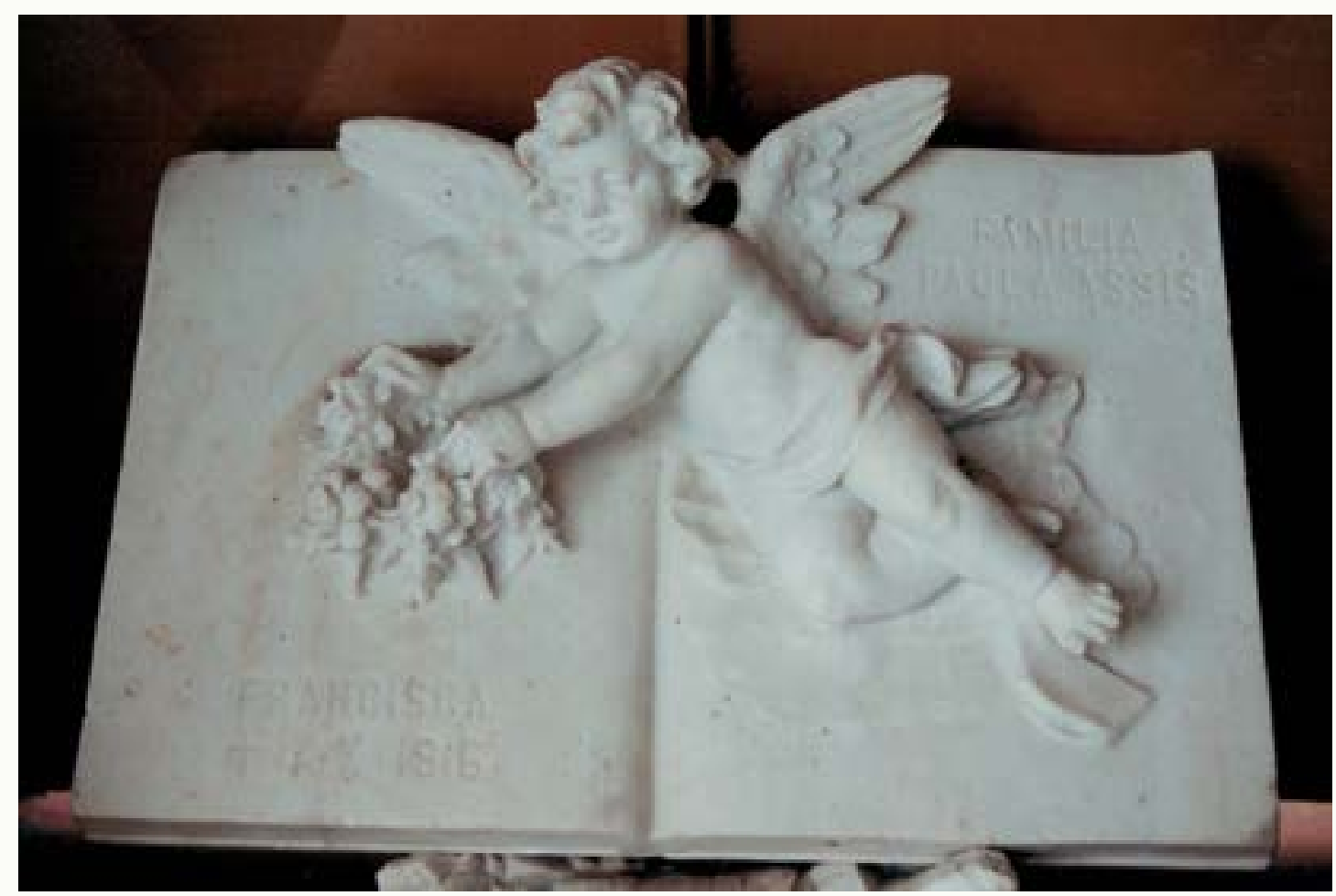

Fonte: Cemitério da Avenida Saudade, Ribeirão Preto (SP). Fotografia: Luciano Bortoletto Júnior.

Outro exemplo de livro aberto que escolhi tem um texto emotivo e carinhoso feito pela mãe de Waldemar, falecido aos 19 anos (1949) e enterrado no Cemitério São João Batista (1851), no Rio de Janeiro. No livro consta a epigrafia: “Em vida fostes o meu consolo e a minha alegria! Agora aceita estas lágrimas de sangue da minha alma que ofereço em sufrágio da tua meiga e boa alminha. [...] "Waldemar *24/8/1930 - †3/4/1949 Saudades de sua mãe". Como ornamento há, em baixo-relevo, um ramo de rosas sem espinho, que, no simbolismo cristão, significa pureza, assim considerada como rosa do paraíso (Keister, 2004). Nesse período já se colocava o retrato do falecido, conforme consta na Figura 4. Estamos diante de uma declaração pública, pessoal, de amor e sofrimento. As letras, as palavras, as sentenças que se aprendem com os professores são transmitidas nos túmulos e ajudam a expressar os sentimentos e a aliviar a dor. 
Figura 4. Livro aberto de Waldemar, mármore de Carrara, 1949

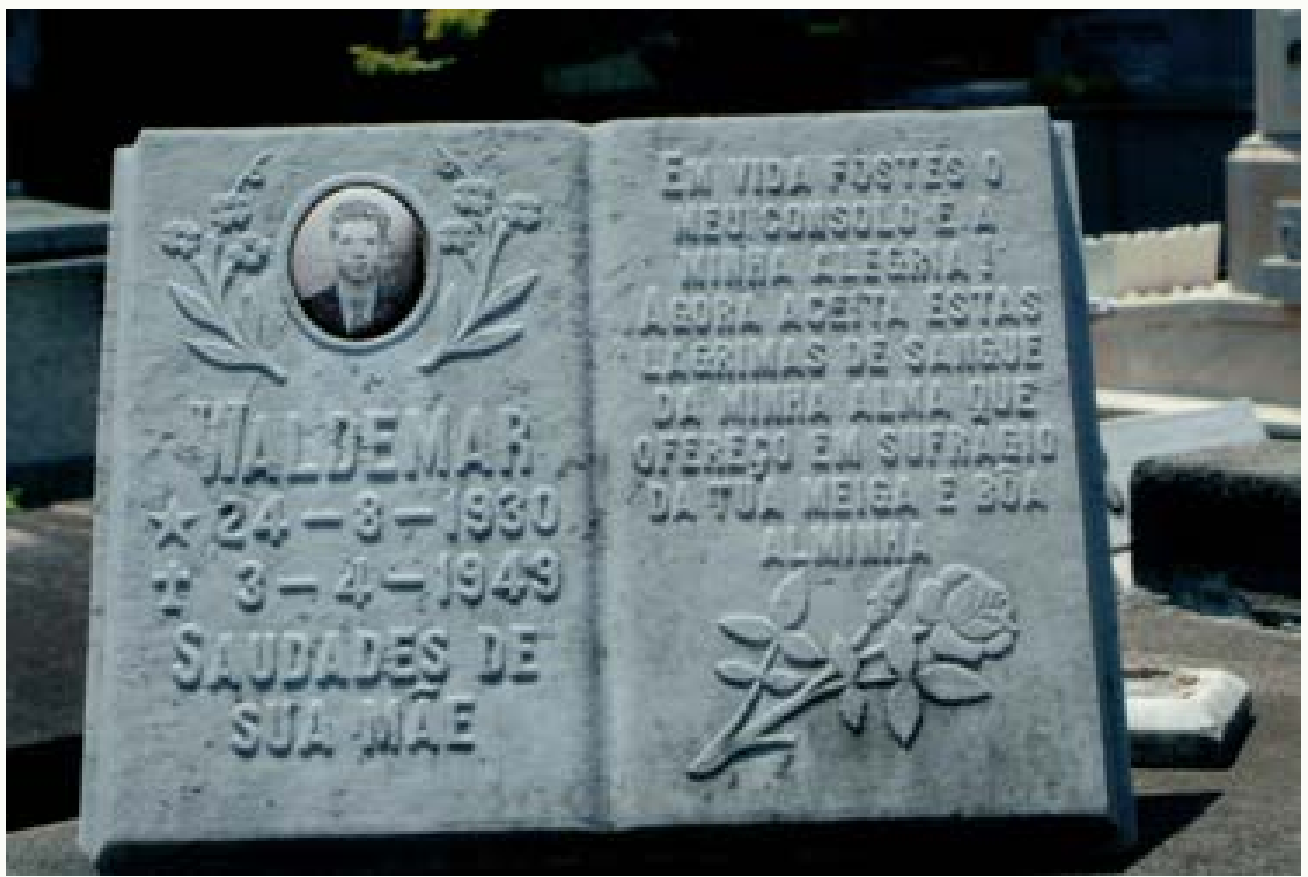

Fonte: Cemitério São João Batista, Rio de Janeiro. Fotografia da autora.

Nos demais cemitérios secularizados no Brasil e no mundo também podem ser encontradas outras representações do livro aberto para homenagear e demonstrar o grau do vínculo literário do falecido. Como exemplo, cito o monumento da família do escritor José de Alencar, no cemitério São João Batista, no Rio de Janeiro, obra analisada no artigo "Retratos memorais: uma das formas de perpetuar a memória de 'Homens Ilustres' nos cemitérios secularizados no Brasil" (Borges, 2012). Coube ao escultor Rodolpho Bernardelli (1852- 1931) instalar "na parte fronteiriça do monumento a representação de um grande e grosso livro aberto - objeto da sabedoria, do conhecimento e local do registro de memória de todos 'os eleitos', segundo a bíblia Cristã" (Borges, 2012, p. 6). Dentro do livro de mármore de Carrara uma cruz romana saliente o separa ao meio e sobre ela foi incorporado um ramo de rosas de bronze. Cada lado do livro é voltado para homenagear um dos mortos com as efígies dos falecidos e os respectivos epitáfios: do lado direito, José de Alencar († 1877), do esquerdo, Georgina Cochrane ( † 1913). Considero essa obra de Bernardelli uma das mais modernas e expressivas do escultor dentro da visão romântica de morte no Brasil.

No meu acervo fotográfico encontrei o túmulo da Dra. Laze Popovica, no Cemitério de Mirogoj, em Zagreb (Croácia), obra realizada pelo grande escultor croata modernista Ivan Mestrovic (1883-1962). Nele também está enterrado o jornalista, colecionador de livros, de arte ingênua e de gravuras e manuscritos do século XV, o sr. Gerhard Ledic (1926-2010) (Kosić; Maleković e Vereš, 1974, p. 67). A justificativa da seleção dessa obra neste artigo advém do diálogo visual que se pode observar na Figura 3. Aqui há um grande livro semiaberto em posição vertical, servindo de cabeceira para o túmulo e, dividindo o livro, uma escultura tão grande quanto o livro de um jovem anjo. Trata-se de uma imagem estilizada, com características modernistas, que 
ainda carrega valores do vestuário da estatuária clássica, com as mãos e as asas apontadas para cima simbolizando a vida celestial, denominada de Alegoria da Ressurreição (Figura 5). Tanto a alegoria da saudade como a da ressurreição estão sobre os livros para traduzir desolação e proteção aos falecidos. Percebe-se que o significado simbólico da apropriação do livro e dos anjos no monumento funerário é atemporal e universal no âmbito da cultura cemiterial ocidental.

Figura 5. Livro aberto com anjo, túmulo de Dra. Laze Popovica e de Gerhard Ledic, mármore de Carrara, escultor Ivan Mestrovic

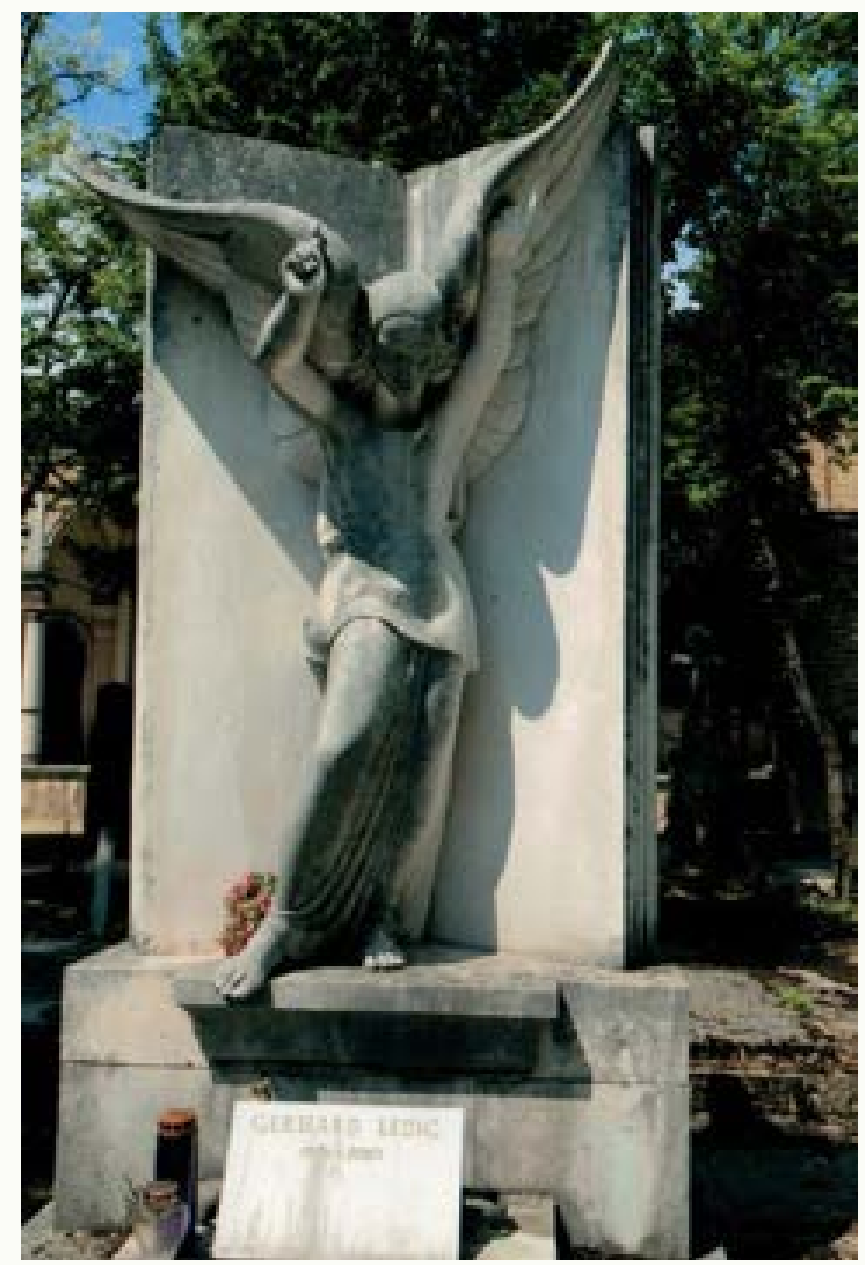

Fonte: Cemitério de Mirogoj, Zagreb (Croácia). Fotografia da autora.

A Idade Moderna avançou muito na feitura do livro, com os novos tipos de impressoras sofisticadas no projeto tipográfico e no design gráfico. A popularização do livro propiciou a valorização da profissão do livreiro, que tem a função principal de disponibilizar os livros editados ao público em geral, vendendo-os em livrarias generalistas ou especializadas. Paul Gustave Doré (1832-1883), pintor, desenhista e ilustrador francês, chegou inclusive a fazer uma caricatura, na qual satiriza a nova mania europeia por livros enormes: trata-se de uma biblioteca repleta de pessoas, uma mulher com dificuldade de abrir um grande livro e os homens sentados 
à mesa à espera do livreiro, que sobe numa escada para pegar os livros (Manguel, 1997, p. 166).

No início do século XX, os escultores recebiam encomendas de monumentos funerários inusitados de parentes, amigos ou de instituições governamentais para prestar homenagens a ilustres falecidos. Tornou-se frequente a representação, no monumento funerário, de objetos de ofício; uma maneira de registrar e valorizar o trabalho utilizado e demonstrar a ideologia burguesa da época.

Para exemplificar o objeto de ofício escolhi a representação do túmulo do livreiro Honoré Champion (1846-1913), instalado no Cemitério de Montparnasse, em Paris, em 1913 (Figura 6). O escultor e pintor Paul-Albert Bartolomé (1848-1928) criou, na cabeceira do túmulo, um nicho onde esculpiu em primeiro plano, em alto-relevo, o busto realista de Champion em contemplação, sentado e voltado para uma mesa, com as mãos sobre um livro. Para representar esse busto de três quartos do livreiro, Bartolomé se inspirou em uma foto de Champion sentado numa cadeira dentro da sua livraria, demonstrando, assim, a preocupação do escultor em fazer um retrato semelhante a ele em relação à expressão do rosto, ao tipo de cabelo, à vestimenta (Figura 7).

Voltando à leitura visual da obra, no segundo plano, a cortina desvela uma estante repleta de livros. Além de livreiro, Champion era dono de uma editora homônima fundada em 1874. Foi membro da Liga da Sociedade Pátria Francesa da História da França, pois também publicava livros sobre história e literatura francesa. Pode-se então atestar a importância que a cultura francesa confere a esse profissional envolvido em livros, tanto na edição quanto na escrita. Certamente foi motivo de honra para a família propor para Paul-Albert Bartolomé esculpir o túmulo, aquele que fizera anteriormente o famoso Monumento aos Mortos, instalado em 1899, no Cemitério Père Lachaise. Sabe-se que, após a morte de Champion, a cidade de Paris prestou-lhe uma homenagem dando seu nome à Square Honoré-Champion, local onde fica a escultura de Voltaire. 
Figura 6. Detalhe, túmulo do livreiro Honoré Champion. Escultor Paul-Albert Bartolomé

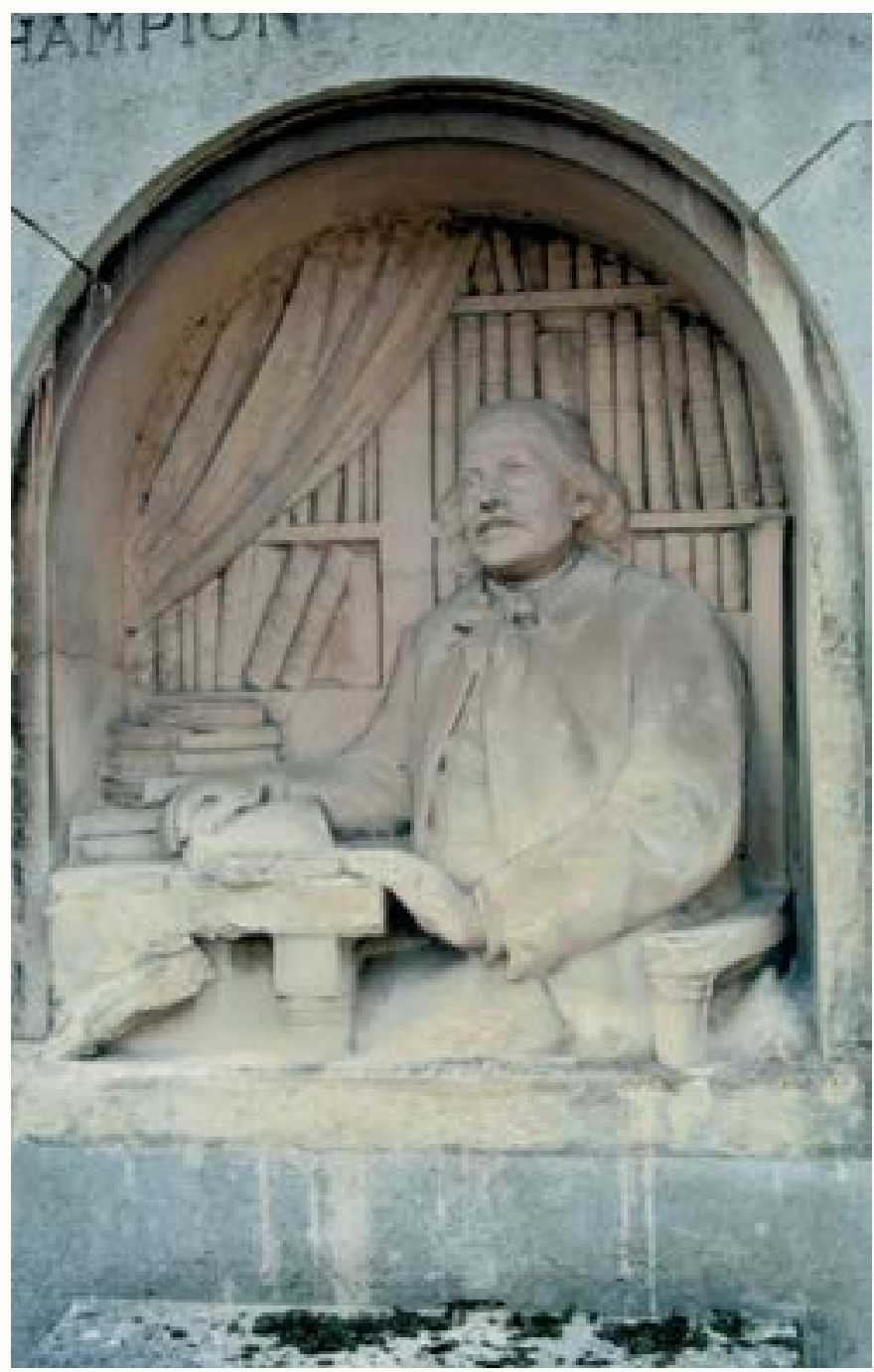

Fonte: Cemitério de Montparnasse, Paris, 1913. Fotografia: Ana Rita Vidica Fernandes. 
Figura 7. Fotografia de Honoré Champion em sua editora e livraria, Paris

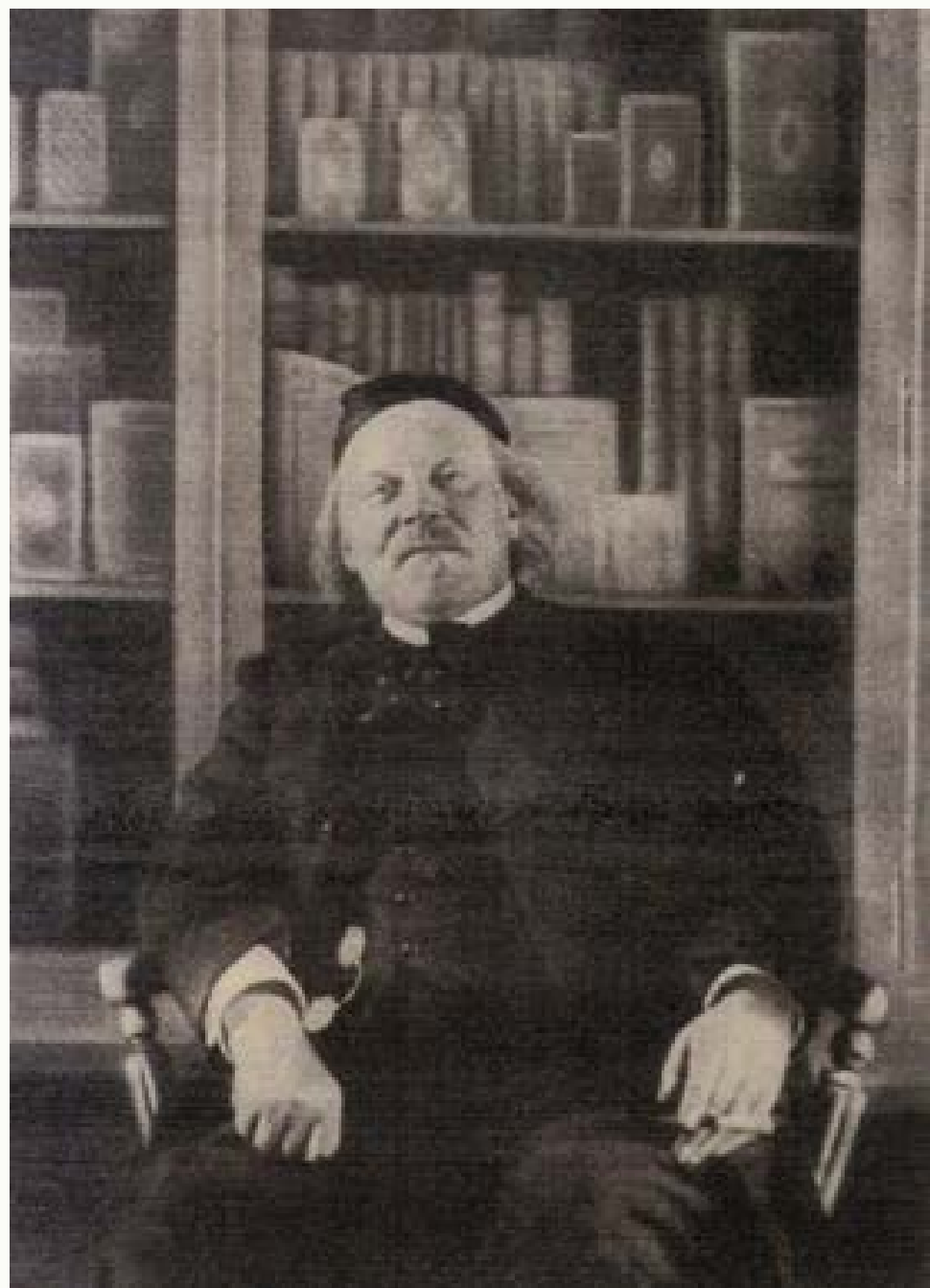

Fonte: Fotografia de Ibanez (1906)2

As imagens até então constituídas neste artigo são decorrentes umas das outras. $O$ escriba "era a mão, os olhos e a voz por meio dos quais se estabeleciam comunicações e se decifravam mensagens" (Manguel, 1997, p. 208); a ampliação da feitura do livro, o ensino da escrita e da leitura transformou a elite aristocrática e burguesa mais comunicativa e reflexiva. Tiveram o poder, inclusive, de transformar a vida dos mortos em memórias vivas com as esculturas dos anjos e os escritos dos epitáfios instalados nos monumentos funerários, repletos de significados e de memória cultural.

\section{Monumentos funerários: o reconhecimento do professor e da escola}

A construção de cemitérios secularizados tornou-se prioridade no Brasil através do decreto imperial de 1828, mas só após a Proclamação da República concretizou-

2 Disponível em: https://wikipedia.org./wiki/Honoré_Champion. Acesso em: 16/09/2019. 
se a obrigatoriedade da sua edificação por todo o território nacional. Muitos deles sofrem ampliações e continuam cumprindo as suas funções: enterrar os mortos independentes da raça ou do credo religioso. Encontram-se, nesses espaços, monumentos funerários construídos em diversos tempos, com um repertório de imagens variadas, todas preocupadas em transmitir uma mensagem aos vivos que visitam os falecidos. Destaco algumas imagens que são homenagens prestadas aos(às) professores(as), à sala de aula e àqueles que foram benevolentes ao contribuírem para construir escolas no Brasil.

A homenagem prestada aos(às) professores(as) deve-se à construção social que a sociedade tem desse profissional, incumbido de várias funções. Cabe a ele "ganhar relevância à cultura escolar, especialmente às relações que estabelece com os alunos" (Penin, 1995, p. 5). O(A) professor(a) deve transmitir um conhecimento erudito, sistematizado, dotado de um método rigoroso que leva a interpretar noções das ciências humanas, das empíricas e das dedutivas e, ao mesmo tempo, educar o pensamento crítico dos alunos para as práticas presentes na vivência do dia a dia. O conhecimento da cultura geral, além do da cultura escolar, sempre renderam, aos(às) professores(as), o respeito e a admiração dos alunos. Vê-se que a afetividade é um aspecto importante para que recebam homenagens póstumas da escola e dos alunos. O imaginário social reafirma esse sentimento pelas narrativas registradas nos monumentos funerários, conforme se vê a seguir.

Alberto Manguel (1997, p. 94) apresenta um túmulo bolonhês, datado da metade do século XIV, no qual consta um professor sentado num banco, segurando um livro aberto diante dele, olhando para a frente, isto é, para seus alunos. Ele parece estar explicando um trecho do livro que leu em voz alta. Abrindo um parêntese, venho demonstrar um costume argentino que vale a pena ressaltar no presente texto. No Cemitério de La Recoleta (1822) existe, em um único jazigo-capela, a proliferação de estelas funerárias de bronze estatuário ou de pedra, feitas por escultores locais e confeccionadas em fundições do ramo em Buenos Aires. São altos-relevos e baixos-relevos simbólicos, que visam valorizar a história das personalidades que ali repousam. Todo ano é passível se colocar mais uma estela, com novos dizeres, reforçando a construção da memória e a comemoração ao falecido. Segundo os pesquisadores Raúl Osvaldo Alesón Moreno, Silvia Rivara e Michel Crespo (2009), muitos desses escultores receberam prêmios no Salón Nacional de Artes Plásticas com as estelas funerárias feitas no começo do século XX.

No meu acervo pessoal tive a oportunidade de registrar estelas funerárias que homenageiam professores (as). A professora Lucrécia Castaños Vivanco (1884-1925) está sendo lembrada por seus docentes e amigos das Escuelas del GE. 18 -n. 8 y Normal Mista de Quilmes. Para isso, o escultor N. A. Ferrari, identificado por Alesón Moreno, Rivara e Crespo (2009), retrata a professora, em primeiro plano, de corpo inteiro, vestida com trajes da época, rodeada por crianças e jovens. Uma obra figurativa com estilização advinda do gosto moderno, datado de 1925 (Figura 8). O carinho da professora pelos alunos se faz representado. 
Figura 8. Estela Funerária para Lucrécia Castaños Vivanco. Escultor N. A. Ferrari, bronze, 1925.

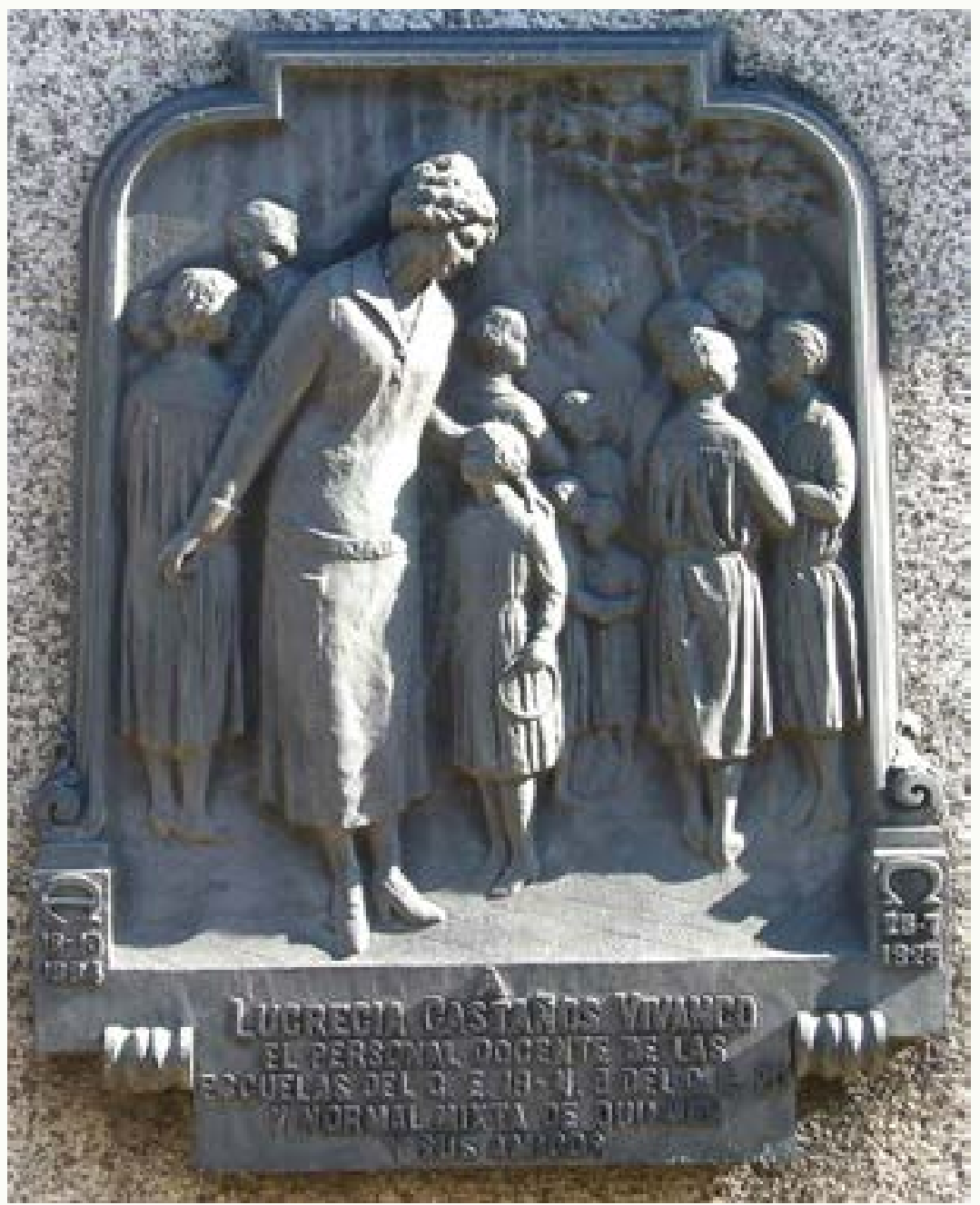

Fonte: Cementério de La Recoleta. Fotografia da autora.

Outra placa, bem pomposa, é a do professor Luis Del Pino (1880-1918), que aparece sentado encostado na coluna partida tendo, ao seu lado, a pira com chamas para o alto. Ele está pensativo, com vestes próprias de um homem dotado de prestígio social. A estela funerária retangular tem na sua base esquerda um ramo de palma e rosas. Todos esses símbolos - coluna partida, pira, palma e rosas - vem justificar a morte desse professor jovem de 38 anos. O campo epigráfico traz uma menção longa: "EL CONSEJO ESCOLAR V ESCUELA SUPERIOR NO. 1 C.N.MARIANO MORENO ASOC. NAC. DEL PROFESSORADO ASOC. Y UNIV. POPULAR BERNARDO DE IRIGOYEN CÍRCULO DE PROFESSORES" (Figura 9). Percebe-se o quanto esse professor era querido pelo corpo docente das escolas em que trabalhou. Outras estelas funerárias voltadas aos(às) professores(as) foram registradas no meu acervo fotográfico, confirmando o respeito que se tinha pelo processo de ensino e aprendizagem representado pelos que a praticam. 
Figura 9. Estela Funerária para Luis Del Pino, bronze, 1918

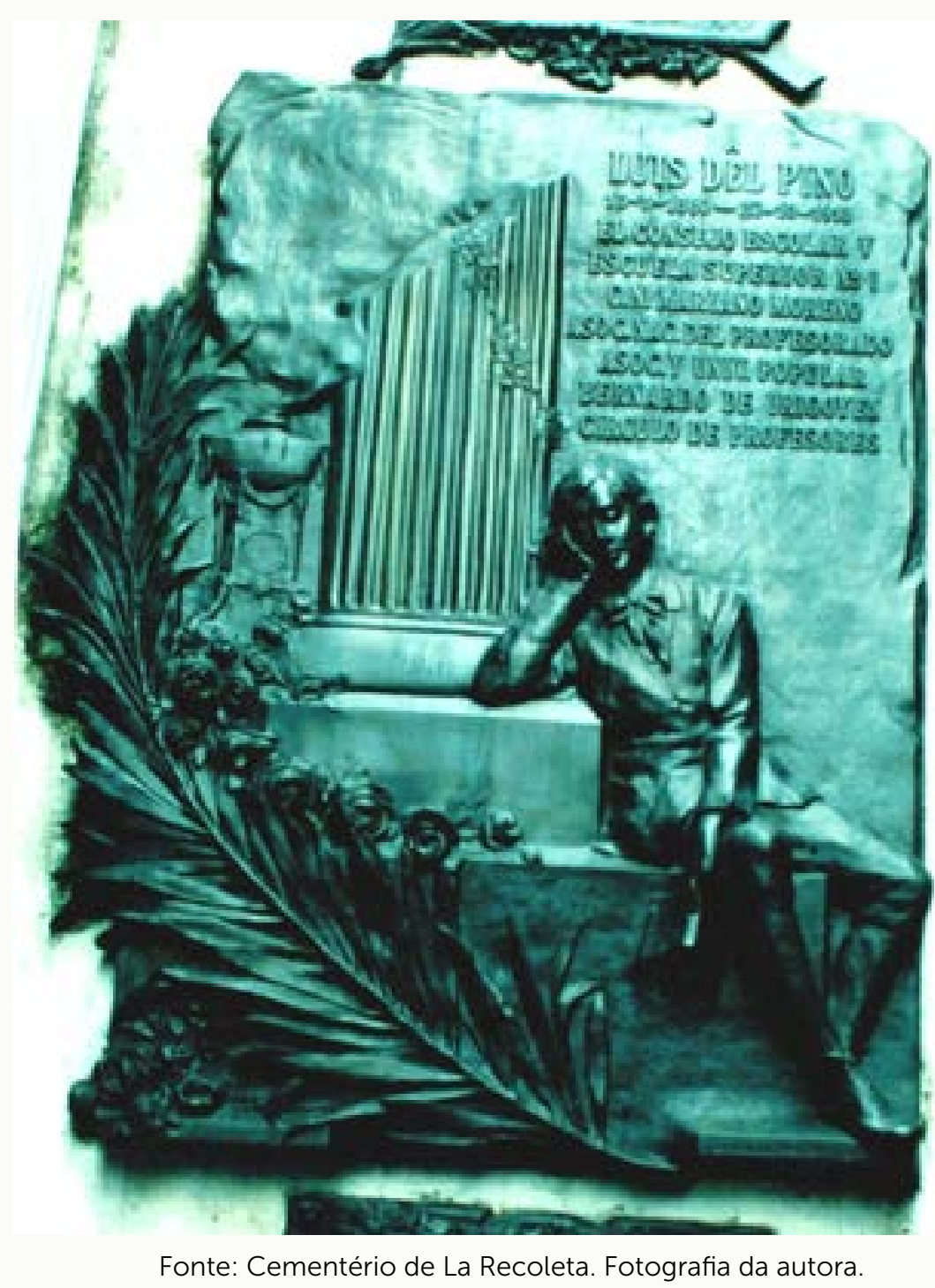

A realidade brasileira da época tem poucos exemplos de monumentos que homenagearam professores(as), mas citamos o caso da professora normalista das escolas Visconde de Ouro Preto e Costa Cena, Lourdes Naves (1925-1958), enterrada no Cemitério Municipal de Bom Jesus, na cidade de Araguari. Seu esposo encomendou um túmulo muito singular. Fez-se uma área similar à entrada de uma casa, recoberta com pedra e com quatro colunas baixas que remetem à cultura clássica. A parede do fundo tem a função de cabeceira e ali está um painel de azulejo com uma narrativa especial (Figura 10).

Nele consta o retrato memorial de $3 / 4$ da professora, cabeça levemente de lado, rodeado por nuvens do céu; ao lado esquerdo há uma escada, onde suas alunas, uniformizadas, clamam por ela, encaminhando-a para o Céu. O painel tem a assinatura da firma Coutinho e Nasi, da cidade do Rio de Janeiro. Trata-se de uma narrativa delicada, que apresenta a morte gloriosa da professora. Segundo depoimento de sua filha Walkiria de Lourdes Naves Oliveira (30/09/2019), a professora Lourdes Naves foi contemplada com uma menção honrosa em 1957, por ter sido 
considerada a melhor professora normalista da cidade. Infelizmente, morreu com apenas 33 anos devido a uma transfusão de sangue. A cidade de Araguari homenageou-a aprovando o seu nome para uma rua no centro da cidade.

O retrato memorial foi reproduzido partindo de uma fotografia provavelmente tirada em uma data especial, haja vista o tipo de pano do vestido, o xale e as joias que complementam o traje social de apurado gosto. Trata-se de uma "semelhança melhorada" (Fabris, 2003, p. 10), ficando difícil distinguir as atitudes morais que concebem ao retratado diante desse fazer artístico que se transforma em uma encomenda de negócio. Aqui ele satisfaz os anseios da família burguesa, que deseja eternizá-la diante da comunidade araguatinense.

Figura 10. Túmulo de Lourdes Naves, 1958

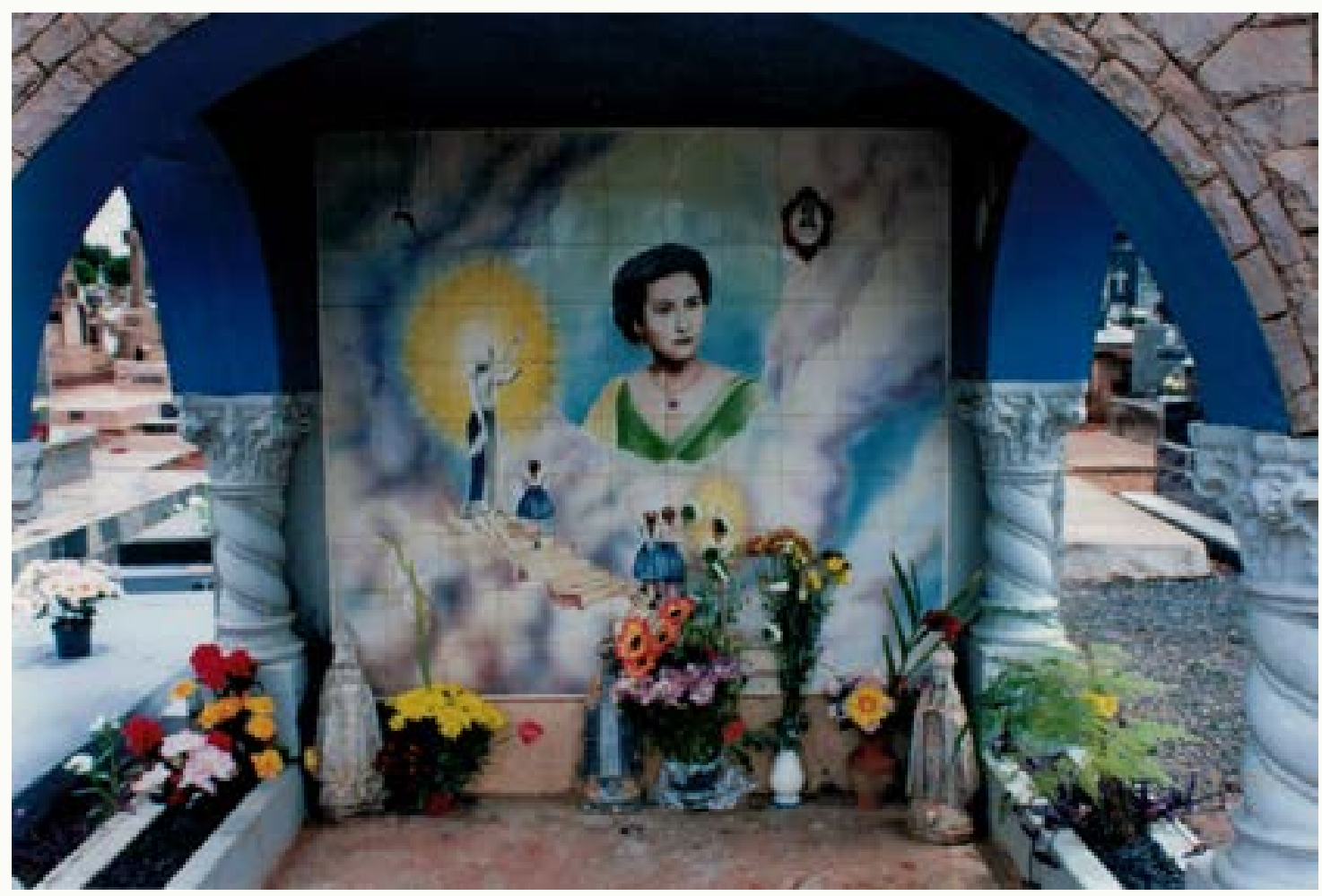

Fonte: Cemitério Municipal de Bom Jesus; cidade de Araguari. Fotografia da autora.

Tanto Lourdes Neves como Lucrécia Castaños Vivanco foram professoras primárias e provavelmente se dedicavam com afinco e amor ao trabalho do magistério, uma atividade de prestígio exercida, em sua maioria, por mulheres integrantes da camada social média da sociedade vigente. Naquela época, o país teve necessidade de investir na educação das crianças e, consequentemente, na instalação dos grupos escolares e das escolas normais no país. O Estado de São Paulo construiu 170 edifícios na rede pública escolar entre 1890 e 1920, uma ampliação de edifícios escolares em prazos relativamente curtos. No livro Arquitetura Escolar Paulista 1890-1920 (Corrêa, Mello e Neves, 1991), as autoras fazem um levantamento das edificações e do processo de restauro com o objetivo de refletir sobre a história da arquitetura escolar paulista com alto valor arquitetônico, histórico e artístico dos 
prédios, permitindo estabelecer paralelos com toda a arquitetura da época. Um dos pontos fundamentais dos ideais republicanos foi a viabilização do ensino primário em larga escala e do poderio econômico do estado de São Paulo, proporcionado pela cafeicultura, que fez com que se investisse em escolas de porte suntuoso. Era também uma das maneiras de valorizar o trabalho da professora.

Na Antiguidade, a escola nasceu como uma necessidade social que visava administrar uma educação coletiva para as crianças. Professor(a) e alunos(as) permaneciam por um tempo juntos em sala de aula. Havia um mobiliário restrito: mesa para o professor, cadeira e lousa, cabendo aos alunos escreverem sobre os joelhos, conforme já descrito em relação à posição dos escribas. Qualquer pessoa que soubesse escrever e ler poderia ser professor, desde que tivesse caráter, honorabilidade e boa formação moral. A profissão do professor era vista como um tipo de ofício humilde e mal remunerado (Marrou, 2017, p. 250-252). Já naquela época sabia-se que a sala de aula melhora a comunicação, é um local de aprendizagem e torna o ensino mais produtivo.

Surpreendentemente, encontrei a representação de uma sala de aula no mausoléu da Maria Izilda de Castro Ribeiro (1897-1911), a Menina Izildinha - O anjo do senhor, na cidade de Monte Alto (SP). Ela nasceu e morreu com 13 anos, em Portugal, vítima de leucemia. A família do seu irmão, que já residia no Brasil, resolveu transladar o seu corpo após 39 anos e a surpresa foi encontrá-la com o corpo intacto, bem como o vestido e as flores que circundavam o caixão. Diante desse fato, ela tornou-se milagreira em Portugal e no Brasil, quando chegou, em 1950, para o mausoléu construído pela família. Ela não é canonizada pela Igreja Católica, mas existem muitos depoimentos de pessoas que falam das graças recebidas por ela. ${ }^{3}$

O Mausoléu (Figura 11) tem um formato levemente ovalado, com escadarias que levam ao primeiro plano, onde se encontra a representação da menina Izildinha, de corpo inteiro, esculpida em bronze; nas laterais há esculturas de livros que remetem à instrução e pães que simbolizam a caridade. Ao fundo existe um grande painel em baixo-relevo, também de bronze, subdividido em duas partes. Na parte direita, mães e crianças estão em pé, como se estivessem orando; na parte esquerda há uma sala de aula, alunos na carteira e um professor escrevendo na lousa. Sabe-se que ela completou o curso primário. Estamos diante de uma narrativa que contempla, de modo realista, o passado de Izildinha na sala de aula e a atitude de devoção do presente e do futuro das pessoas devotas ao seu redor. Atrás do mausoléu existe uma sala com objetos doados pelos milagreiros. Todo mês de junho realiza-se a Festa da Menina Izildinha, cuja renda é revertida em prol do Educandário Menina Izildinha, que acolhe crianças e adolescentes.

Não é comum encontrar esculturas que retratam o corpo inteiro do falecido, isso acontece apenas em casos muitos especiais, de homens que se tornaram grandes empreendedores dentro do sistema burguês vigente. Esse caso é uma maneira especial, pois garante o valor simbólico da retratada por cultuá-la como santa. Ali está concentrada uma prática devocional diante da história de vida da menina Izildinha. Ela de corpo inteiro, mesmo

3 Disponível em: htps://pt.wikipedia.org./wiki/Menina_Izildinha. Acesso em 30 de setembro de 2019. 
"idealizado", satisfazendo os anseios da comunidade de Monte Alto e de sua família; uma representação de cunho afetivo voltado aos valores religiosos e sociais que identificam o local de devoção. Na lateral do monumento encontra-se uma fotografia da menina Izildinha com os seguintes dizeres: "IZILDINHA, O ANJO DO SENHOR, PROTETORA DAS CREANCINHAS". Não se tem a intenção, no presente texto, de aprofundar questões que envolvem o processo de santificação, e sim demonstrar que ela certamente valorizava a escola ali representada e que com certeza serve de estímulo até hoje para as crianças que lá visitam.

Figura 11. Mausoléu da Menina Izildinha. Esculturas em bronze, monumento em estrutura de tijolo pintado de cor clara, 1950

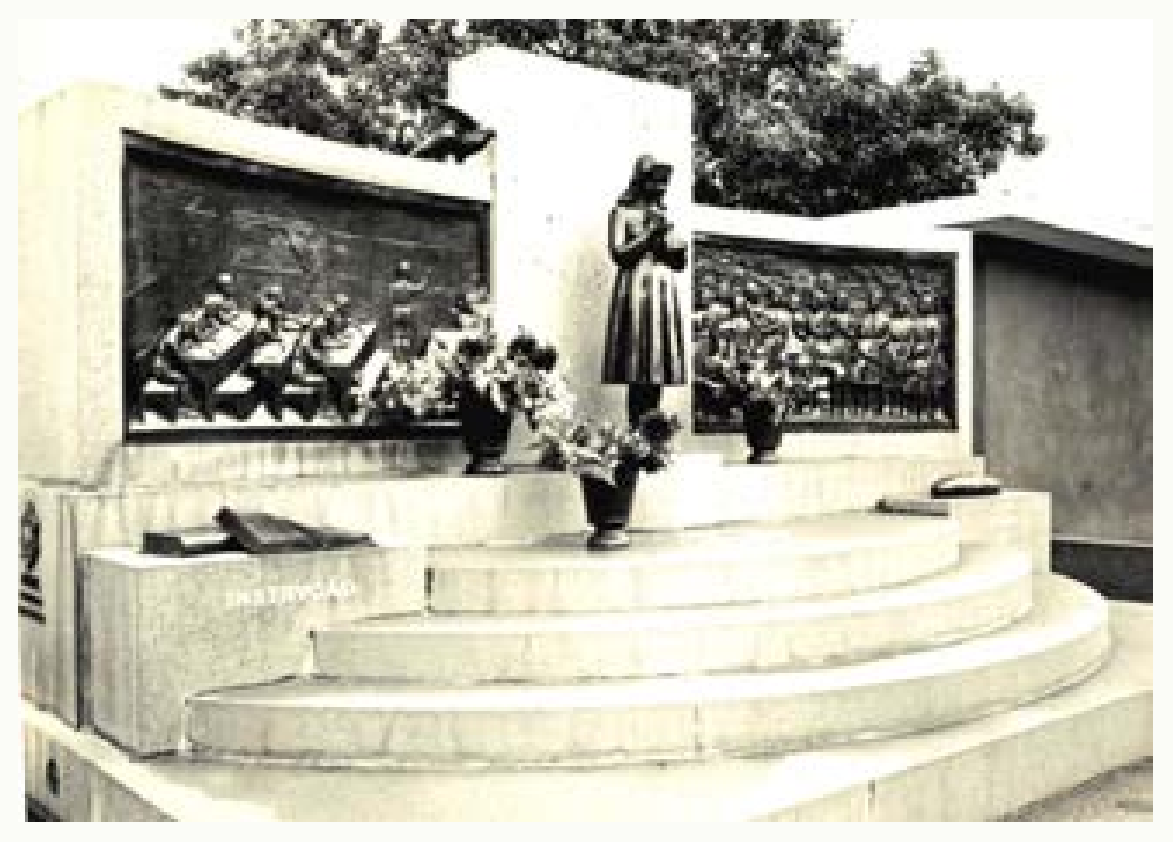

Fonte: Cidade de Monte Alto (SP). Fotografia da autora

Destaco, ainda, o episódio de uma pessoa que, em seu monumento funerário, deixou registrada a síntese de seus feitos como empreendedor e com atos beneficentes voltados para a escola e as instituições de saúde. Geralmente os benfeitores são pessoas de grande poder aquisitivo, que se destacam na sociedade em que viveram por ajudarem a população por meio de atitudes generosas. É o caso do espanhol Manuel Barreiro Cavanelas (1867-1950), que imigrou para o Rio de Janeiro com 16 anos. Seu monumento funerário está retratado no Cemitério São João Batista, no Rio de Janeiro (Figura 12). Trata-se de uma obra com base alta e grande, que cobre todo o jazigo revestido em mármore escuro.

$\mathrm{Na}$ base do monumento está assentada a herma do falecido com os seguintes dizeres: "Dai às crianças escolas. Aos doentes hospitais. E aos velhos asilos". A herma de bronze- retrata o busto da pessoa sem braço - está em posição frontal, sendo dotada de realismo, conforme se pode observar na expressão do rosto, careca e com rugas condizentes com seus 83 anos. A veste elegantíssima representa o traje social masculino da época: terno, colete e gravata longa, símbolos do status social daquele homem imigrante bem-sucedido. 
Atrás da herma, sobre a base do monumento, encontra-se um conjunto de quatro arcos assentados em colunas, que lembram o formato dos arcos da cultura moura, em torno de um cubo retangular que contorna toda a base. O interior de cada arco possui uma narrativa em bronze sobre os seus atos filantrópicos. Na narrativa atrás da herma do sr. Cavanelas vê-se a representação realista de uma escola em perspectiva, em baixo-relevo e no primeiro plano; em alto-relevo, crianças uniformizadas conversando entre si e uma delas com um livro na mão. No título desse painel estão os dizeres: "Escolas na Espanha e asilos no Brasil". Essa é a frente do monumento com a cruz trevolada na parte superior da construção (Figura 12).

A biografia do sr. Cavanelas traz fatos pitorescos da vida desse homem, considerado irreverente para a época. Ingresso no Clube dos Fenianos, um clube carnavalesco criado antes da Proclamação da República, custeado por ele e demais componentes do clube, foi apelidado de "gatarrão". Queria que "seu clube desfilasse com alegorias vistosas, com críticas ferinas". Também foi grande benemérito da Sociedade Espanhola de Beneficência e construiu, no bairro da Tijuca, o Recreio dos Anciões, em 1940. A sua fortuna adveio do jogo do bicho, se estendeu para a fábrica de roupas femininas e para negócios de hotelaria. Após a sua morte, um decreto municipal, em 1955, deu seu nome a uma rua na estação de Brás de Pina. ${ }^{4}$

Manuel Barreiro Cavanelas foi conhecido na Espanha como Conde de Cabanelas, cujo título nunca foi reconhecido pela rainha María Cristina, pois ele nunca mais voltou a morar em seu país. Foi benfeitor na Província de Pontevedra, colônia de Covelo, onde nasceu e, em uma de suas visitas, construiu duas salas do hospital Provincial de Pontevedra; contribuiu para a urbanização de Covelo; edificou escola em Laxedo, obras deterioradas pela Guerra Civil. ${ }^{5}$

4 O Jornal, 30 de janeiro de 1965 apud EFEGÊ, Jota. Figuras e Coisas do Carnaval Carioca. Rio de Janeiro: Funarte, 1982, p. 45.Disponível em: <https://cifrantiga2.blogspot.com/2012/06/manuelcavanelas-e-o-clube-dos-fenianos.html>. Acesso em 30/09/2019.

5 HERMIDA, María. Traslospasos de un conde que nuncalo fue. Disponívelem: https://www.lavozdegalicia. es/noticia/pomtevedra/a-lama/2017/10/14/tras-pasos-conde-nunca/0003_201710P14C12991.htm. Acesso em: 30/09/2019. 
Figura 12. Monumento de Manuel Barreiro Cavanelas, 1950, revestido de mármore escuro e esculturas de bronze

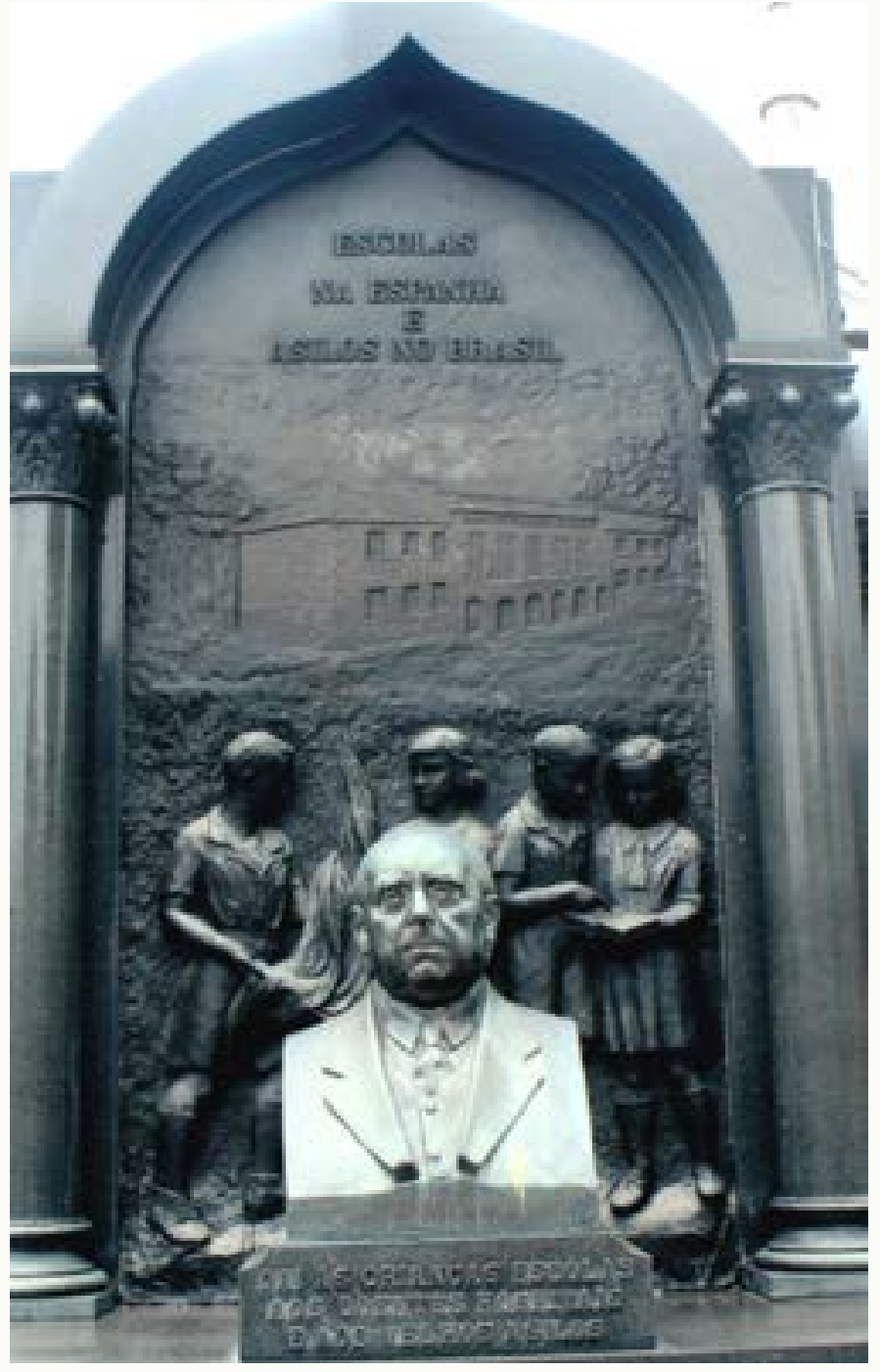

Cemitério São João Batista, Rio de Janeiro. Fotografia da autora

A herma foi um tipo de escultura muito utilizada nos cemitérios secularizados no começo do século XX. Aqui ela está confirmando a função de preservara memória individual do falecido no espaço em que estão depositados os seus restos mortais e as narrativas visuais vêm confirmar a eternização do estado social de Cavanelas, que foi reconhecido pela sociedade do Rio de Janeiro por seus gestos filantrópicos, segundo a construção de sua biografia de vida.

$\mathrm{Na}$ forma de retrato memorial, busto, herma, corpo inteiro e de narrativas teve-se uma valorização desse universo biográfico que visa eternizar a memória individual que representa todos os dados vinculados à educação. Os retratos foram colocados dentro de um espaço estratégico no monumento, uma maneira de valorizá-los enquanto pessoas e educadores. A maioria das obras foi realizada por marmorarias locais que colocavam placas de identificação, todavia, com o tempo, elas desapareceram e não se tem como reconhecer a origem das esculturas e do monumento funerário. Há outro lado da escolha dessas imagens, que é o seu significado narcísico, capaz de registrar as particularidades "idealizadas" do falecido nos 
monumentos funerários, local propício para perenizar o indivíduo revalorizado após sua morte. Acredito que essa foi uma atitude dominante da época.

\section{Considerações finais}

A trajetória do artigo abrangeu obras instaladas em vários cemitérios secularizados do Brasil: Cemitério Senhor Bom Jesus, em Batatais; Cemitério de Santa Casa de Misericórdia, de Porto Alegre; Cemitério da Avenida Saudade, em Ribeirão Preto; Cemitério São João Batista, no Rio de Janeiro; Cemitério Municipal de Bom Jesus, em Araguari. Pude verificar, assim, que as homenagens aos educadores independem do tamanho da cidade e do cemitério, mas sim do valor cívico apregoado a eles. Um caso especial selecionado foi o da cidade de Monte Alto, que liberou a construção de um monumento funerário no centro da cidade, em 1950, transgredindo as normas vigentes do país que impedem o enterro de pessoas em espaços fora dos cemitérios. A obrigatoriedade advém do Decreto Federal n. 7.899, de 27 de setembro de 1889 (Borges, 2017, p. 197).

As obras me possibilitaram inferir que há uma influência grande dos valores da estatutária clássica em várias imagens, como os traços físicos e corporais da mulher em Batatais e o corpo e a vestimenta de Clio. Os adornos como a coluna partida e colunas com capiteis florais também remetem ao gosto greco-romano, assim como a representação do retrato memorial em forma de escultura ou pintura. Mais realista ou mais idealizada, conforme aparece nas demais obras, o retrato "se torna público e traz consigo a representação da "aura" da pessoa (Marques, 2008, p. 59). Trata-se de uma imagem erigida que nunca poderá substituir o retratado, todavia, tem a função de evocar o passado e perpetuar a recordação, segundo Raphael Fonseca (Borges, 2012). Retratar os mortos representava uma honraria voltada para poucas pessoas, mais para homens. A sociedade burguesa, nos séculos XIX e XX, volta a empregar o retrato memorial, conforme consta neste artigo, às pessoas dedicadas ao ensino, à educação e ao saber. São retratos que levam em consideração a pose, a indumentária e os atributos que ajudam a construir a identidade social da elite intelectual da época (Borges, 2012, p. 160).

Eles seguem os modelos adotados nos jazigos biográficos-celebrativos construídos para políticos e artistas, custeados pelo governo em vários cemitérios do Brasil. Os retratos memoriais eram indispensáveis. O historiador Arnoldo Walter Doberstein (2002, p. 194) analisa esse gênero de monumento construído no Cemitério da Santa Casa de Misericórdia, na cidade de Porto Alegre e destaca o quanto eles simbolizam de maneira despojada uma manifestação do poder contida de uma "dissimulação da realidade objetiva [...] quase nada é inocente". Acredito que o monumento de Manuel Barreiro Cavanelas pode ser visto dentro desse ideário político considerado por Doberstein.

Atualmente ainda existem enterramentos em cemitérios secularizados no Brasil e podem-se construir monumentos funerários decorados com insígnias que referendam os educadores. Todavia vivenciam-se novos hábitos culturais no processo funeral como a crescente procura pela cremação, onde os valores morais do falecido são pronunciados 
apenas no discurso de despedida ou no enterramento em cemitérios jardins que empregam uma placa pequena para identificação do morto. As homenagens póstumas personalizadas se restringem aos anúncios de jornais e aos santinhos de sétimo dia, e que no espaço de tempo curto são jogados fora.

Quando ponderei no início do artigo a atitude atual de expropriação do saber da educação, levei em consideração a crescente desvalorização do salário da professora primária, que permanece exercida só por mulheres. No início do século XX era vista como a principal profissão feminina que propiciava a mesma entrada no mercado de trabalho como pertencente a uma população economicamente ativa. A crise institucional genérica do país, advinda do estágio de desenvolvimento urbano-industrial e os obstáculos de ordem psicossocial e sociocultural estão impedindo o ajustamento das escolas ao meio social vigente, conforme relata Luiz Pereira (1969) quando trata da questão do magistério primário numa sociedade de classes. Para Maria Eliana Novaes (1984), uma das provas desta situação está na forma de como chamam atualmente as professoras primárias - Tia - uma imagem muito próxima da tia na família desapropriando mais uma vez o saber da professora.

De todo modo, a memória individual tornou-se pública e acessivel a todos que caminham pelas ruas dos cemitérios secularizados. Persiste também a comunicação dos laços afetivos de carinho, de agradecimento e admiração impregnados entre alunos (as) e professores (as), partindo da escrita para se chegar a essa relação que perdura para além da morte.

\section{Referências Bibliográficas}

ALESÓN, Raúl; RIVARA, Silvia e CRESPO, Michel. Relevamiento de estelas y propuesta de recorridos en el interior del Cementerio de la Recoleta. Buenos Aires. In: X Encuentro Iberoamericano de Valoración y Gestión de Cementerios Patrimoniales. Colombia, Medellín, 2009. [CD-Rom].

ALVES, José Francisco. A escultura pública de Porto Alegre: história, contexto e significado. Porto Alegre: Artfolio, 2004. 264p.

ANDREWS, Carol. The Ancient Egyptian book of the dead. London: British Museum Press, 1996. $192 p$.

BELLOMO, Harry (Org.). Cemitérios do Rio Grande do Sul: arte, sociedade. Ideologia. Porto Alegre: EDIPUCRS, 2000. 281p.

BORGES, Maria Elizia. Retratos memoriais: uma das formas de perpetuar a memória de "Homens llustres" nos cemitérios secularizados no Brasil. In: V Encuentro Iberoamericano de Valoración y Gestión de Cementerios Patrimoniales. Rosário/Província de Santa Fé, 2012. [CD- Rom].

BORGES, Maria Elizia. Busto memorial: retrato idealizado convertido em "brasão burguês" póstumo. In: Anais do VII Encontro da Associação Brasileira de Estudos Cemiteriais. Rio de Janeiro, 2015. [Cd-rom]. 
BORGES, Maria Elizia. Arte funerária no Brasil (1890-1930): Ofício dos marmoristas italianos em Ribeirão Preto. 2ำ edição. Goiânia: Gráfica UFG, 2017.432p.

CORREAA, Maria Elizabeth Peirão; MELLO, Mirela Geiger de e NEVES, Helia Maria Vendramini. Arquitetura escolar paulista: 1890-1920.São Paulo: FDE/Diretoria de obras e serviços, 1991.172p.

DOBERSTEIN, Arnoldo Walter. Estatuários, catolicismo e gauchismo. Porto Alegre: EdiPUCRS, 2002. 372p.

FABRIS, Annateresa. A guerra das imagens. In: ZIELINSKY, Mônica (Org.). Fronteiras: artes, crítica e outros ensaios. Porto Alegre: Editora UFRGS, 2003, p. 10-25.

FEBVRE, Lucien e MARTIN, Henri Jean. O aparecimento do livro. São Paulo: Unesp, 1992. 574p.

ISMÉRIO, Clarisse. Mulher: a moral e o imaginário 1889-1930. Bagé: Editora da Urcamp, 2018. $112 \mathrm{p}$.

KEISTER, Douglas. Stories in stone. A field guide to cemetery symbolism and iconography. Salt Lake City: Gibbs Smith, 2004.288p.

MANGUEL, Alberto. Uma história da leitura. São Paulo: Companhia das Letras, 1997. 405p.

MANGUEL, Alberto. Lendo imagens: uma história de amor e ódio. São Paulo: Companhia das Letras, 2001. 358p.

MARQUES, Luiz. A fábrica do antigo. Campinas: Editora da UNICAMP, 2008. 408p.

MARROU, Henri-Irénée. História da Educação na Antiguidade. Campinas: Kírion, 2017. 679p.

KOSIĆ, Krešimir; MALEKOVIĆ, Vladimir e VEREŠ, Saša. Mirogoj Zagreb: 1873-1993. Zagreb: Grafičkizavod Hrvatske, 1974. 80p.

NOVAES, Maria Eliana. Professora primária. Mestra ou tia. São Paulo: Cortez editora, 1984. 143p.

PENIN, Sonia Teresinha de Souza. A professora e a construção do conhecimento sobre o ensino. Caderno Pesquisa. São Paulo, n. 92, p. 5-15, fev. 1995.

PEREIRA, Luiz. O magistério primário numa sociedade de classes. São Paulo: Pioneira, 1969.

SILVEIRA, Tatiana de Carvalho Silveira. A escultura funerária no Rio Grande do Sul: política e ideologia 1990-1950.In: BELLOMO, Harry (Org.). Cemitérios do Rio Grande do Sul: arte, sociedade. Ideologia. Porto Alegre: EDIPUCRS, 2000, p. 123-143.

Recebido em: 15 de outubro de 2019

Aprovado em: 04 de dezembro de 2019 